\title{
Psyche, Nightmare and Religion: Precursors of Colonial Conquest in Ahmed Yerima's Attahiru
}

\author{
Taiwo A. Stanley Osanyemi (Corresponding author) \\ Department of General Studies, Federal Polytechnic Ede, Osun State, Nigeria \\ E-mail: taistanley@yahoo.com \\ A. A. Oladipupo \\ Department of General Studies, Federal Polytechnic, Ede, Osun State, Nigeria \\ A. O. Michael \\ Department of General Studies, Federal Polytechnic, Ede, Osun State, Nigeria
}

Doi:10.7575/aiac.alls.v.8n.3p.32

URL: http://dx.doi.org/10.7575/aiac.alls.v.8n.3p.32
Received: 08/03/2017

Accepted: 19/05/2017

\begin{abstract}
This paper is premised on the connection between history and drama in order to profile the historical characters or heroes and explicate the socio-political predicament in their society. Existing studies on historical plays have focused on the celebration and chronicling of the heroic deeds of the historical characters, sometimes ignoring the artistic techniques the playwright employed. This study, therefore, examines psyche, nightmare and religion as the stylistic techniques for establishing the sources of disintegration in an imperial environment. This is with a view to investigating the link between the conflicts of the protagonist and the predicaments of his society. The study is based on psychoanalysis that allows for the investigation of characters' unconscious motives and collective archetypes. The text, Attahiru is subjected to critical textual analysis in both content and form to analyse the paradigmatic use of history, dream and religion to account for the colonial conquest of an African society. Various patterns of unconscious archetypes such as psyche, nightmare, daydream and religion were discovered to serve as techniques of foreshadowing and flashback to the physical and psychological conflicts in the play. They serve as signifiers of the protagonist's traumas. These unconscious archetypes, therefore, have become the catalysts for disintegration and veritable strategy in Ahmed Yerima's account of imperial history.
\end{abstract}

Keywords: Psyche, Nightmare, Religion, History, Disintegration, Colonial conquest

\section{Introduction}

Attahiru is a play that depicts the heroic resistance to British imperialism by the Islamic Sokoto caliphate. It is a dramatisation of historical Sultan Muhammadu Attahiru I of Sokoto during colonial rule under the leadership of Fredrick Lugard in the early 19th century Nigeria. The title, Attahiru is eponymous of the hero and protagonist of the play who ascends the throne in November in 1902 as the twelfth caliph of Sokoto and Sarkin Musulmi. Existing studies on Attahiru have focused on the celebration and profiling of Attahiru as a historical hero who suffers as a result of domineering nature and attack of British colonialists in his caliphate with little or no consideration for the innate and attributive characteristics of the monarch that contribute immensely to the imperial subjugation and conquest of his kingdom. This, of course, is the crux of thi paper.

In the history of northern Nigeria and Islam in Nigeria, Sokoto remains a great influence and the seat of the northern religious and political power. This is also brought to focus in the play. The caliphate under Attahiru, as seen in the text, is a strong military power with unalloyed loyalty of the people to the constituted authority and religion, which is Islam. Caliph Attahiru I wears the crown and holds the baton of leadership that is laden with both spiritual and physical responsibilities. Unfortunately, Attahiru, the hero and protagonist, is enthroned at a critical and turbulent period. When the colonialists are waxing stronger in their bid to capture and control the social, economic and political activities of both the northern and southern protectorates of Nigeria, Attahiru has reigned for barely six months before the irresistible British military penetrate the northern communities. This British military penetration is so fierce that it captures and controlls some northern towns and cities that are notably warlike and more militantly dexterous and skilful than Sokoto, the major setting of the play and also the seat of the caliphate. These cities are Kano, Zaria, Kontagora and others. The news of the successful penetration and conquest of the British forces prepares the ground for the resistance championed by Attahiru I in the Sokoto Caliphate.

As Phillip Holden (2011:22) affirms that "anticolonial life narratives and plays are not unconcerned with community and the community-defined nature itself...", the resistant attitudes of Sokoto as championed by Attahiru emanate from the theories of Islamic concept of international relations, which are opposed to non-Islamic government (Akoh, 
2007:116). The brief synopsis of the play shows that there is a great shaking and fear in the land, which is introduced by the news of the defeat of Kano by the Lugard's soldiers and his intention to do the same in Sokoto. This news comes when there is a vacancy on the throne. So, symbolic and intriguing as this may be because the vacant throne suggests absence or non availability of a political leader at this critical period, the people of the Sokoto caliphate are eagerly looking unto whosoever will be the new caliph to lead the war against the British force. This is the reason why Yerima begins the play with the coronation of Attahiru as the new Sultan and the great furore that follows the coronation. The furore portends that the new caliph will declare war against British intrusion and uphold the flag of Islam.

As this is the expectation of the people, the new leader, Attahiru, finds himself at cross-roads wondering whether to fight Lugard and his men or allow peace and friendship to reign, which negates some sacred principles of Islam. His state of mind is presented in these lines:

I am becoming the caliph at a time when the history of our lives is at a delicate balance. At a time when the whiteman is determined to upset the peace of our lives. But it is too early to dare enemies, or look for one. (Attahiru, 21)

This leads to a summon of the meeting of the ruling members of the caliphate where the majority advises the Caliph to declare war. However, there are some who wish for peaceful cooperation and negotiation with the colonial warlord. During the deliberations, a letter is received from the Luggard warning the Caliph to cooperate peacefully lest he faces the colonial antagonism and wrath that may completely destroy his people and reign like other neighbouring northern kingdoms. The Caliph, Attahiru I, and his people resolve that there is no room for friendship between believers in Islam and non-believers and infidels, the white men. The refusal of Luggard's call for friendship sparks off the anger of the British colonialists and they declare war against the Caliphate. But Lugard promises not to interfere with the people's religion so as to have a permissible advantage to take control of the caliphate completely. The war is fought outside the gate of the city. Lugard and his men become victorious. Attahiru first escapes to seek military alliance from Islamic neighbours from Kano, Zaria, Gombe and Ilorin who have allowed peaceful economic relations between their kingdoms and the British colonialists. In spite of the alliance, the Caliphate suffers and a good number of lives are lost including Caliph Attahiru I.

The accuracy of the historical content of this text is inconsequential. Rather, the psychoanalytical critique of the text shall be done. It will be done by looking at the structure and technique the playwright puts in place to present the issue of colonialism in the northern part of Nigeria. The issues to be discussed centre on the portrayal of psyche, nightmare and religion as techniques and precursors of disintegration and conquest during the era of British imperialism in northern Nigeria and psychoanalysis will be the theoretical framework of this research. Psychoanalysis, according to Barry (2002:97), is "a form of therapy which aims to cure mental disorders by investigating the interaction of conscious and unconscious elements in the mind" The essence of psychoanalysis in drama is to show audience that the repressed fears and conflicts which are causing the problems in a dramatic piece are brought into the conscious mind and openly faced, rather than remaining buried in the unconscious. It is within this purview that we shall look at the specific impacts and influences of Attahiru as a historical and fictional hero in the play.

\section{Aesthetics of Psyche}

Right from the beginning of the play, Yerima focuses on the mind of the protagonist. He portrays the emotional feeling of Attahiru as the main bane of conflict of cultural contact. Immediately after the enthronement of Attahiru, he begins to have internal fears about the socio-political situation of his domain. This escalates into a misgiving in his heart over whether his reign will be characterised by peace and political success or not. His short and maiden speech as the Caliph attests to this:

I am becoming the Caliph at a time when the history of our lives is at a delicate balance. At a time when the whiteman is determined to upset the peace of our lives. But it is too early to dare enemies, or look for one. I shall await their moves. But let us pray for Allah's hand in the matter. Let us pray for peace. Let us pray for our children, let us pray for the growth of our lives and position in the Islamic world. Thank you all. (Attahiru, 21)

Yerima artistically privileges the state of the mind of the protagonist above the excitement and celebration that must accompany the coronation of a king. Even the conciseness of the speech is a pointer to the fact that the presenter is in a pensive mood occasioned by the prevailing social, economic and political situations in the land. It can be seen from the speech that there is a repressed fear and psychological imbalances in the personality of the protagonist and the hero. This speech also reveals a lot about the characterisation of Attahiru; it shows that he is a man that is very reflective and will readily yield to the dictates of his mind.

To worsen the repressed fear and imbalance in his heart, there is the land and well dispute between two prominent members of his society, Sarkin Zango and Sarkin Fatake. This dispute portends internal disintegration in the land. To combine internal problem with the external problem and fear from the looming British encroachments will become too cumbersome and turbulent to his unconscious mind. Therefore, he makes an appeal thus:

Like good Muslim brothers, we must find common grounds for peace. The times we are in are not times for land and well problem. We all heard what happened to great Kano. The Emir, Aliyu who 
you earlier mentioned never arrived Kano after he left Sokoto. Now, I hear he has fled for his dear life. This worries me, and indeed should worry us all. Even now as I speak the whitemen trouble me with letter begging us to be friends. I find them a difficult people to understand. They throw dust of shame all over the place, and yet with their bloody hands they want you to shake and embrace them while the dust of shame settle on your face. We Muslims must stick together in these trying times, and not allow Shaitan create disharmony amongst us. May Allah forbid this (Attahiru, 25-26)

It is unfortunate to describe this king as a weakling in this context. Yerima, here, has presented a leader that is not assertive as a result of his confused state of mind. Attahiru fails to assert himself and his domain heroically. The author even reveals to the audience, from his state of mind, that he will lead his people to destruction without getting to the Promised Land.

Yerima aesthetically presents the psychological mindset of the hero, Attahiru, as the aesthetic technique of the plot structure and as the vehicle for the development of characters. Caliph Attahiru is presented as showing feelings of dejection and failure when it comes to international matters. This similarly reveals to the audience that Yerima's hero and protagonist is a weakling who will never survive the pangs of colonialism. This is a reflection of Shakespearean view that cowards die many times before their time but the valiant taste death but once. Lord Lugard sends a letter about his coming to Sokoto. He has not even come when Attahiru begins to have a premonition of defeat. The conversation between Attahiru and his son, Mai Wurno, attests to this:

CALIPH: $\quad$ Promise me two things for as the blood of Sheu Dan Fodio flows in your veins, that you will never allow the infidels capture the flag of Islam and therefore extinguish the light of our people

MAI WURNO: Never Baba

CALIPH: $\quad$ Second, that you will never attempt to make yourself by force, the Sarkin Musulumi after me. Allah chooses the Caliph. If Allah chooses you then, may your reign be a peaceful one, if not hold on only to the light.

MAI WURNO: $\quad$ I give you my word father. Yet, I do not understand, we are only four months into your reign (Attahiru, 39).

This premonitory talk surprises even the son, because his father has just spent four months on the throne and he is foreshadowing or predicting an untimely end to his throne. This is also surprising to the audience because a peace talk has neither started nor a disagreement between the caliphate and the colonial lords ensued. What has happened is only the transmission of a letter asking for peace talk. It is, therefore, suffice to say that, Yerima presents the psyche of his fictional character to reveal the plot structure's complication and denouement.

The essence of the presentation of human psyche at the expense of the historical conflict is to privilege the individual weakness and strength above the social, cultural and historical conflict. Yerima uses the mindset of Attahiru to redefine history of the colonisation of northern Nigeria to show the distinction between the conscious and the unconscious mind of the colonised. What Attahiru ought to have done in action, he allows his mind to over dwell on in theory. This results in his ineffective handling of a critical and historic issue like colonialism.

\section{Aesthetic of Nightmare}

A remarkable and effective technique the playwright employs is nightmare. The major effect of nightmare is to create fear, anxiety, discomfort and terror to the dreamer, which will later affect his or her decision, actions and inactions (Adeboye, 2010; Cleary, 2008; Harris, 2009 \& Hollis, 2000). Nightmare often puts a searchlight on the thinking ability of the dreamer and it propels the dreamer to face up to the challenges of real life.

In Attahiru, Caliph Attahiru has a nightmare that makes him to be restless and anxious in his conscious mind. He becomes inquisitive to know the likely implication or the interpretation of the symbolic creations that surface in the dream. Consequent upon the nightmare, he summons his two sons and Mallam (Koranic teacher and spiritual guardian) in order to know the direction of his reign and society. He narrated his nightmare:

I had a dream; it has become more repeated in recent times. It worries me... Always, it starts in the early hours of the morning there is smoke, heavy smoke, it is at the battle field. Dead warriors littered everywhere. Then images of my ancestors appeared in a circle round me. They pass the flag from one hand to the other. As they chant lailaha, illalah, I watched helplessly stretching my hands to collect the flag. I watched helplessly as Caliph Atiku gives it to Muazu, then to Caliph Umoni, then to AbdulRahman, and as he passes it to me, the flag falls, dripping blood. In all this smoky confusion, Dan Magaji tries to help me pick it up, but he is tripped by a white pebble, he too falling on his sword. The dream subsumes me in thought...... Oh wise Mallam. (41).

The crucial symbolisms in this nightmare are religion and war, the flag obviously representing Islam (religion) while "battle field, dead warriors and blood" symbolise war and death. It should be noted also that the nightmare has been a reccurring one and its re-occurrence proves what Freud (Thurschwell, 2000:47) calls symbolic condensation, which is a 
presentation of dream where a number of people, events or meanings are combined and represented by the image in the dream. From Attahiru's nightmare, there is transference of emotions in the dream to the conscious actions. He watches helplessly as the flag is tossed from one hand to another. Similarly, he fails to take a reasonable step to dialogue before declaring war against the white men who are more advanced militarily.

Yerima successfully presents dream (nightmare) in Attahiru as part of history that has the ability to present various human experiences at different times and spaces. Thus, intrinsically, the nightmare expresses, though obliquely, the pain, euphoria and illusions of cultural contacts and its effects on the colonised and colonisers.

It is a fact that nightmares, just like drama, do not usually make explicit statements. Both tend to communicate indirectly, avoiding direct or open statement, quite unlike history, and representing meanings through concrete embodiments of time, place, person and interpretation. The nightmare becomes meaningful explicitly to Attahiru when his Mallam has given his personal interpretation as:

The prophecy... Your highness... No one is sure now but it is said that after Sheik Usman Dan Fadio has started his work, and has started to spread the word of Islam conquering kingdoms, there was a prophecy that his caliphate shall exist for a hundred years ..... No one gave them a thought again, until recently when talk of the fall of Yola, Zaria, Kano, Kotangora and Ilorin, all flag bearers under the caliph started to lose their freedom to the Whiteman. Just as it was The beginning of the end. (42)

Yerima uses this nightmare and its interpretation as a device of foreshadowing which preconditions the hero's psychological disposition in order to beautify and advance the plot structure. In reality, nightmare and its interpretation hardly rise beyond premonitory note, but Attahiru's state of mind makes the interpretation of this dream to transcend premonition, making it to become a fulfilment because of over- reliance on Mallam's interpretation.

The psychological and physical disposition of Attahiru to nightmare and its interpretation has been depicted to show the characterisation of the Caliph as a feeble man who lacks force, vigour or efficiency in action. No wonder, he embraces or swallows Mallam's interpretation hook, line and sinker. However, his reaction to the interpretation might be in alignment with Islamic fatalistic view that fate is irreversible. It would however, have been better if he had allowed his conscious mind to exercise just a little thought, which may have lessened the tragedy. His tragedy lies in his indecisiveness over the collective unconsciousness and the conscious manifestation. His unwarranted resignation to fate is coagulated on his religious obsession as it can be seen below:

If indeed, there is prophecy that must end Sheu's Empire in my reign as Caliph, then, this is no time to mourn, but a time of gratitude. A time of prayers and great thanks to Allah that I am the chosen one. A time to stand firm, defending the faith, and carrying out the wish of the Almighty (pause).

And what can I say to him but Alhamdulilahi (Attahiru, 43)

The playwright employs the various strands of human collective unconsciousness to synthesise all manners of events, ideal and beliefs that characterise the northern Nigeria in Attahiru. Yerima, through presentation of human psychic context and nightmare, interrogates the sympathetic and symptomatic tension associated with colonial history. He presents the euphoria and the reality of cultural contact as things that are capable of existence without the anxieties, worries and agitation the colonised African ascribe to colonialism. He seems to pontificate further that the colonial masters lord it over the colonised because of their psychic perception of the presence of white in their domain. He does this artistically in such plays as Attahiru, Attah Ameh Oboni and The Trial.

It is pertinent to know again that after the tragedy of the killing of Attahiru's soldiers by Lugard's men, Attahiru daydreams and sees all the catastrophe that has befallen his domain as prerequisites for religious and social respite. It is quite unfortunate that his daydreaming or fantasy does not yield the needed succour or respite because he hopes to shatter the dreams of the white man (Lugard). It is the white men who shatter his socio-political desire. However, he has a spiritual solace in his religious injunction. His daydreaming here is likened to a nostalgia. Attahiru hopes that hijra (holy flight) will spell doom for the Whiteman:

on our way to Mecca, we put to shame the whiteman's dream of conquering the servants of God. There on the sandy plain of Bebeji we spread the ego of the whitemen like small desert sand dunes for camel's hooves to knock down (Attahiru, 60).

But he never lives to undergo the flight because of the attack from the whiteman he plans to surprise. The explicit cause of this great defeat Attahiru suffers is religion, which plays a prominent role in his personal decisions and aspirations.

\section{Religion and Religiosity}

Religion is a phenomenal aspect of human mind and life. Religion is seen as belief in and worship of a supernatural controlling power, especially a personal god or gods. It is also seen as the practice that someone or some groups devote their entire life to. Attahiru is a play that exemplifies people's strong obsession with religion. Attahiru strongly believes and devotes his time, life and activities to religion, specifically Islam. All his actions and inactions are informed by religion. Religiosity, on the other hand, is the quality of being too religious. 
Samuel Huntington (2002:11) and Watanabe (2003:17) posit, "religion shows men that do not live by reason, men that cannot calculate and act rationally in pursuit of self interest and common goal, to these people religion provides compelling answers". This is exactly the case with Caliph Attahiru I. Yerima deliberately portrays religion as part of the necessary condiments to $\mathrm{x}$-ray the psychological mind frame of the protagonist, Attahiru. It will be highly expedient to examine the effects and areas of religiosity in the personality of Attahiru and his people.

In the plot structure of the play, there is an option opened to Attahiru and his court officials, either to choose peace and cooperation between the British and his people or choose war:

Tell the infidel that we did not invite him to interfere with our problems. He has his religion and we have ours ... as my predecessor Caliph Abdutraham had earlier said the only relationship that can exist between a believer and an infidel is... war! (33).

From the above, an infidel is a person that does not belong to or believe in Islam. It suggests that it is only a believer in Islam worthy to be dialogued with. The failure to embrace peace talk results in the erosion of peace and unity in the land. Lugard knows that the northern people of Nigeria are too engrossed with religion. Therefore, he prepares for them. Attahiru's religiosity prevents him from seeing the other side of strangers who are not Muslims. Lugard declares that his intention is not to fight but Attahiru causes it " the whiteman did not just start the fight, he was provoked. He came as a friend and your Caliph said no, so we fight your Caliph, fighting a visitor is wrong (Attahiru, 55).

David Ekanem (2012:13) posits that "for enriching knowledge and scholarships in African post colonial discourse... the historical settings of the dramas and narratives are important to provoke new perspective in thinking or envisioning the realities of the old African world against the backdrop of colonial landscape". Bearing this view in mind, the artistic success of Attahiru as a re-interpretation of events surrounding the conquest of the Sokoto Caliphate can be aligned to the way in which the playwright places the issue in the context of Islam (religion). It is true that the play captures the nationalistic zeal and yearnings of the Caliphate and their leaders when it comes to decision-making and it portends their over-dependence on the dictates of their religion.

In a careful examination of the characters in the play, it will be seen that the playwright uses religion as an instrument of disintegration rather than integration and unity. The protagonist is engrossed with religion but other members of the society and of the same religion allow the white men peace talk to prevail. The playwright, from the various attitudes of the Northern Emirate to religion and strangers, portrays dramatic effect of irony. Ironically, the warriors of the Emirates of Kano, Gombe, Kontagora and others come together to help Caliph Attahiru to wage war against the British force. These allied Emirate forces could not help themselves against British forces when the white men come to their kingdoms. They make an agreement of friendship but the question that lingers is why then the show of solidarity for the Caliph. The futility in joining forces to fight the white men who are militarily superior to the Emirate forces is instructive. This ridicules the level of psychological and intellectual thinking of the members of the Emirates. This makes the play to reflect or depict the psychic context of the characters over or above the historical predicament.

Another area where the unconscious state of mind becomes an integral part of the discussion is the irony seen in the play by some of Attahiru's palace chiefs, that is Waziri, Madawaki, Sarkin and Kwani who recommend war and hijra for the Caliph but when the British force eventually captures the Caliphate, they decline from following Attahiru. They welcome the stay of Lugard and his men. They even suggest the choice of a new Caliph to Lugard while Attahiru I is still alive; "I am the Waziri of Sokoto, our Caliph Attahiru has left Sokoto and we the remaining people here want peace "(Attahiru, 50). This Waziri is the one who suggested war before and he is now seeking peace. The playwright's artistic use of religion and betrayal in this context still points to the fact that he creates characters that are feebleminded, characters that do not have strong will like Lugard and his forces.

\section{Conclusion}

It is, therefore, appropriate to say that the author places the psyches of the characters far above the historical conflict. The playwright successfully depicts that the psychological and religious desire of the historical character and fictional hero, Attahiru, is a mere wishful thinking and this shows why the real purgation of emotion that usually accompanies tragedy or tragic hero is lessened. This finding does not agree with Uwatt's (2007) submission that the conquest of European colonialist over Attahiru's caliphate is largely due to internal disunity and intrigues among Attahiru's subjects. The finding also contrasts Akoh's claim that attributes the fall of Attahiru and his caliphate to imperialist pseudo friendship. There are options to thwart the trend of the tragedy but because of dreams, their interpretation and religion, the protagonist, Attahiru, faces a tragic end. He is more portrayed or seen as a martyr than a tragic hero.

\section{References}

Adeboye E.A. (2010). Digging Deep - part two. Lagos: Tie Communication Ltd.

Akoh, A. (2007). Towards a historiography of the text: the plays of Ahmed Yerima. Muse and mimesis. Gbemisola Adeoti. Ed. Ibadan: Spectrum. 110-122.

Barry, P. (2002). Beginning theory, and introduction to literary and cultural theory $2^{\text {nd }}$ edition. Manchester: Manchester UP. 
Cleary, A. (2008). Recognition memory, familiarity and dejavu experience. Current directions in psychological sciences 17 (5). 253-357.

Ekanem D. (2012). Narrative, Memory and the politics of national liberation: the autobiographies of Kwame Nkrumah, Oginga Odinga and Nelson Mandela. Unpublished seminar paper for staff and postgraduate students, Department of English, University of Ibadan.

Harris, W. V. (2009). Dreams and experience in classical antiquity. London: Harvard University Press.

Holden, P. (2011). Missing in action: the strange case of imperial autobiography Madison: Wisconsin up.

Hollis, J. (2000). The archetypal imagination. Texas: A \& M University Press.

Huntingson, P. Samuel. (2002): The clash of civilisation and the remaking of world order. London: Simon and Schuster.

Thurschwell, P. K. (2000). Neurophysiology neuroscience and mind. Indian journal of Psychological medicine. 71-73

Uwatt, E.B. (2007). Yerima's theatre and Nigerian history: The trials of Oba Ovoranwem and Attahiru. Muse and Mimesis. Gbemisola Adeoti. Ed. Ibadan: Spectrum Books Ltd. 123-142.

Watanabe, T. (2003). Lucid dreaming: its experimental proof and psychological conditions. Journal of international social life and information science 21(1). 48-62.

Yerima, Ahmed. (1999). Attahiru. Ibadan: Kraft Books Limited. 